\title{
Vulnerability as a path to a 'social minimum'? An analysis of ECtHR jurisprudence
}

Dimitrios Kagiaros*

\section{Lecturer in Law, University of Exeter}

Submitted as a chapter in I. Leijten, T. Kootkas and F. Pennings (eds), Specifying and Securing a Social Minimum in the Battle Against Poverty (forthcoming, Hart Publishing 2019)

\section{Introduction}

The chapter examines the capacity of the European Court of Human Rights (henceforth ECtHR or 'the Court') to establish a social minimum of welfare provisions that states would owe to all individuals within their jurisdiction. The European Convention on Human Rights (ECHR) is a human rights treaty primarily aimed towards the protection of civil and political rights. ${ }^{1}$ The jurisprudence of the ECtHR, however, has demonstrated that a strict distinction between first generation (civil and political), and second generation (economic, social and cultural) rights is outdated. ${ }^{2}$ The Court seems to embrace the theory of the indivisibility of rights and has argued that the mere fact that an interpretation of the Convention may require the state to provide socioeconomic assistance is not in itself a reason against such an interpretation. ${ }^{3}$ To that end, the obligations states have to secure the effective enjoyment of ECHR rights, ${ }^{4}$ in conjunction with the Court's approach to interpreting the Convention in light of its objective and purpose, ${ }^{5}$ have opened up 'gateways " 6 for the civil and political rights protected in the ECHR to generate socioeconomic obligations on states. Relying on the doctrine of positive obligations in relation to various Convention articles, ${ }^{7}$ the Court has succeeded in identifying certain limited Convention-based socioeconomic duties to which states must adhere.

Nevertheless, the ECtHR's case law relating to socioeconomic rights is to a large extent characterised by timidity and deference to the respondent state. ${ }^{8}$ The circumstances in which

\footnotetext{
*Lecturer in Law, University of Exeter, UK.

${ }^{1}$ Some rights that would fall under the umbrella of socio-economic rights are also protected in the ECHR, including the right to education protected under Article 2 Protocol 1 ECHR. See also the chapter by Leijten in this volume.

${ }^{2}$ See for instance Airey $v$ Ireland (App. No. 6289/73, 9 October 1979) para 26.

${ }^{3}$ Ibid.

${ }^{4}$ Colm O'Cinneide, A Modest Proposal: Destitution, State Responsibility and the European Convention on Human Rights (August 30, 2008). Available on SSRN: https://ssrn.com/abstract=1370241 or http://dx.doi.org/10.2139/ssrn.1370241

${ }^{5}$ Ibid.

${ }^{6}$ Ibid.

${ }^{7}$ Primarily Articles 2, 3, 6, 8, 14 and Article 1 Protocol 1 ECHR. See indicatively Ellie Palmer, Beyond Arbitrary Interference: The Right to a Home? Developing Socio-economic Duties in the European Court of Human Rights, 61 Northern Ireland Legal Quarterly pp 225-43 (2010).

${ }^{8}$ It is not uncommon for a case that requires substantial reallocation of resources to be declared inadmissible as manifestly ill-founded. See for instance Botta v Italy (App. No. 21439/93, dec, 24 February 1998); Zahnalova and Zehnal v Czech Republic App. No 38621/97, dec, 14 May 2002); Sentges v Netherlands (App. No. 27677/02, dec, 8 July 2003). On the approach of the ECtHR to socio-economic rights see indicatively I Leijten, Core SocioEconomic Rights and the European Court of Human Rights (Cambridge University Press, 2017) and Ida Elisabeth Koch, Human Rights as Indivisible Rights: The Protection of Socio-Economic Demands under the European Convention on Human Rights (Martinus Nijhoff Publishers, 2009).
} 
the Convention will require states to adopt 'socioeconomic' measures are exceptional, as the Court does not view itself as a forum for socioeconomic litigation nor as a protector against poverty and destitution. ${ }^{9}$ Additionally, the few judgments where the Court has found that the state owed socioeconomic duties to the applicant are characterised by a lack of uniformity, ${ }^{10}$ thus hampering the development of a principled approach to socioeconomic jurisprudence at the ECtHR.

This chapter contributes to a specific dimension of the debate on the ECtHR's capacity to protect socioeconomic interests and to generate a social minimum of welfare protection. Building on the chapter by Leijten in this volume, it examines the relationship between the state's positive obligations in the socioeconomic sphere and the applicant's 'vulnerability'. Vulnerability, the state of being 'open and exposed to hurts and harms of various kinds ${ }^{11}$ has begun to feature prominently in the ECtHR's case-law, including in cases with a socioeconomic dimension. This chapter argues that vulnerability can serve as a useful normative justification for the Court to be less deferential to the respondent state and to interpret the Convention in a manner that generates obligations in the direction of a social minimum. Additionally, the chapter discusses the limitations of vulnerability analysis in this context and makes suggestions on how this tool could be developed to further build a path towards a social minimum under the ECHR.

The arguments will be developed as follows. Part II establishes the meaning of a minimum core obligation. This will serve as the basis to determine whether there is any indication that the ECtHR could generate a similar obligation under the Convention. Part III examines the nature of positive obligations in human rights law and explains how these have affected the Court's approach in its socioeconomic case law. Emphasis will be placed on the fact that positive obligations are obligations of means. They require states to take steps to protect rightsholders from threats to their rights that are attributable to third parties or general situations. The appropriate steps the state must take vary depending on the circumstances of the case and what could reasonably be expected of the state in dealing with the situation before it. Therefore, the chapter concludes that these are obligations that are subjective as they vary among states. In the socioeconomic sphere, the Court has granted states a particularly wide margin of appreciation to determine how they will allocate their resources and it has been reluctant to inflate the scope of positive obligations in a manner that would create onerous financial duties for the contracting parties. Part IV examines instances where the Court, in spite of the subjective nature of positive obligations has demanded socioeconomic provisions from states but in a manner that is objective, namely where they are the same for all states and must be immediately complied with, regardless of the specific capabilities of each state. The Court has set such objective socio-economic standards where the applicant is a member of what the Court considers to be a vulnerable group and is wholly reliant on state support for her subsistence. In such cases, the Court will demand that the basic needs of the vulnerable individual are met by the state regardless of the wide margin of appreciation the Court usually grants where the state's capacity to allocate its resources is concerned. The chapter argues that

\footnotetext{
${ }^{9}$ See Pancenko v Latvia (App. No. 40772/98, dec, 28 October 2009) para 2.

${ }^{10}$ On this see Janneke Gerards, 'The ECtHR's Response to Fundamental Rights Issues Related to Financial and Economic Difficulties - the Problem of Compartmentalisation' (2015) 33 Netherlands Quarterly of Human Rights pp 274-92.

${ }^{11}$ Mary Neal, 'Not Gods but Animals: Human Dignity and Vulnerable Subjecthood' (2012) 33 Liverpool Law Review pp 186-187.
} 
the vulnerability criterion is a tool the Court can rely on to transform what would normally be subjective obligations into objective standards of protection that are meant to apply across all state parties to the ECHR. This, however, does not generate a social minimum that would protect all from destitution, as the protection is available exclusively to the members of specific groups that the ECtHR has identified as vulnerable. Part V discusses whether expanding the notion of vulnerability to encompass a greater number of individuals in need could become the normative justification the Court relies on to demand social minimum protection from state parties to the ECHR. The chapter concludes that while some expansion of the concept would be useful, the Court is rightfully wary of inflating it. An approach that reconciles the group dimension of vulnerability with the individual needs of the applicant could be the best path the Court could follow towards recognising a social minimum of protection while also protecting its legitimacy.

\section{Minimum Core Obligations in International Human Rights Law}

The protection states are expected to provide to socioeconomic rights in international human rights law is closely linked to the concept of 'progressive realisation'. ${ }^{12}$ In the International Covenant on Economic Social and Cultural Rights, this duty to progressively realise socioeconomic rights is connected to the 'available resources' ${ }^{13}$ the state has at its disposal. Thus, the state is not expected to guarantee that all socioeconomic demands will be fulfilled instantaneously. Instead, it must demonstrate that it is working towards the full realisation of the right by taking concrete steps in that direction. Alongside the obligation to progressively realise rights, states have an obligation to immediately fulfil a certain minimum of socioeconomic demands regardless of their resources. These represent the minimum core of the right. This core is primarily ${ }^{14}$ understood to be inviolable, non-derogable, and must be fulfilled regardless of the subjective capabilities of the state. ${ }^{15}$ Thus, even states with limited resources must give priority to the fulfilment of their minimum core socioeconomic duties.

In his analysis of such minimum core obligations, Tasioulas argues that they possess three key characteristics. Firstly, minimum core obligations are characterised by their immediacy; 'they demand immediate compliance' rather than progressive realisation from the state. ${ }^{16}$ A second characteristic is their completeness, which requires states to ensure that minimum core demands are 'fully complied with at any given time'. ${ }^{17}$ Thirdly, minimum core obligations are understood to be universal 'in that they bind all states'. ${ }^{18}$ In relation to this final criterion, Tasioulas additionally recognises that these obligations bind all states in the same

\footnotetext{
12 International Covenant on Economic, Social and Cultural Rights, GA Res 2200 (XXI) A (UN Doc A/6316) (Dec. 16, 1966) Article 2.

${ }^{13}$ Ibid.

${ }^{14}$ Some also argue that it is not an absolute standard based on the wording in UN Committee on Economic, Social and Cultural Rights (CESCR), General Comment No. 3: The Nature of States Parties' Obligations (Art. 2, Para. 1, of the Covenant), 14 December 1990, E/1991/23 para 10.

15 See Diane Desierto, Public Policy in International Economic Law: The ICESCR in Trade, Finance, and Investment (Oxford University Press, 2015) pp 68-179.

16 John Tasioulas, 'Minimum Core Obligations: Human Rights in the Here and Now' (2017) pp 20 http://documents.worldbank.org/curated/en/908171515588413853/pdf/122563-WP-Tasioulas2-PUBLIC.pdf .

${ }^{17}$ Ibid.

${ }^{18}$ Ibid.
} 
way, namely their content is understood to be 'invariant across states'. ${ }^{19}$ Thus, while progressive realisation creates subjective standards on the states as it is linked to their available resources, minimum core obligations are primarily seen as objective in nature and are the same for all states irrespective of the state's wealth. This understanding of minimum core obligations seems to mirror discussions in political philosophy of a social minimum which Waldron defines as 'a level of material well-being beneath which no-one should be permitted to fall' ${ }^{20}$

While the ECHR does not include explicit references to progressive realisation and the ECtHR does not employ this terminology, its approach arguably recognises the subjectivity of positive obligations. The following section will illustrate the approach the Court has developed before proceeding in the remainder of this chapter to assess instances where the Court has tentatively departed from such an analysis to identify a minimum core-type duty on the state by relying on the applicant's vulnerability.

\section{The subjective nature of Positive Obligations the case law of the ECtHR}

Human rights obligations under international law are not limited to the negative type of protection that traditionally is synonymous with civil and political rights, and call upon the state to refrain from any unwarranted interference with the enjoyment of a right. ${ }^{21}$ They also develop a positive dimension which requires the state to act preventatively and protect the individual from wrongful acts that threaten the enjoyment of her rights and are attributable to third persons or general situations. ${ }^{22}$ In such cases, even though the prejudice to the right is not directly attributable to the state, the state is still required to take all necessary steps to protect the rights-holder. These steps depending on the circumstances may include an obligation to provide redress to the victim of a violation by a third party, to carry out an effective investigation, ${ }^{23}$ to provide material assistance to the rights-holder or to punish the third-party wrongdoer. This positive dimension of rights is where the duty to provide socioeconomic assistance would arise, as the state would be required to take action, or at least not to remain passive, in order protect the rights-holder from a situation of destitution that could violate her rights.

However, the duty of the state when its positive obligations are under examination is to take steps to protect the rights-holder. All the state must demonstrate is that, given the exigencies of the situation, it was diligent in mobilising its resources to the best of its abilities to fulfil its duty to protect. It does not have an obligation to succeed in protecting the rightsholder. ${ }^{24}$ There are further prerequisites for this duty of the state to act to be triggered. For

\footnotetext{
19 Ibid at 23. Some scholars see it as a variable standard. See for instance Craig Scott and Philip Alston, 'Adjudicating Constitutional Priorities in a Transnational Context: A Comment on Soobramoney's Legacy and Grootboom's Promise' (2000) 16 South African Journal of Human Rights pp 206-68.

${ }^{20}$ Jeremy Waldron, 'John Rawls and the Social Minimum' (1986) 1 Journal of Applied Philosophy 21, 21.

${ }^{21}$ Civil and political rights, however, also generate positive obligations under the Convention, see Alastair Mowbray, The Development of Positive Obligations Under the European Convention on Human Rights by the European Court of Human Rights (Hart, 2004).

${ }^{22}$ Ibid. See also Laurens Lavrysen, Human Rights in a Positive State (Intersentia, 2016).

${ }^{23}$ See for instance Nachova and others $v$ Bulgaria (App. Nos 43577/98 43579/98, 6 July 2005).

${ }^{24}$ For a thorough account of positive obligations and the state's duty of due diligence see ILA Study Group on Due Diligence in International Law, First Report Duncan French (Chair) and Tim Stephens (Rapporteur) published 7 March 2014 pg 16, www.ila-hq.org/download.cfm/docid/8AC4DFA1- 4AB6-4687A265FF9C0137A699.
} 
instance, the state must have known (or ought to have known) of the danger to which the rightsholder was exposed. ${ }^{25}$

Once it is established that a duty of the state to protect exists, the Court must then define the scope of this obligation. What must the state have done to protect the rights-holder in the specific circumstances? The tools the Court relies on to respond to this question are helpfully summarised in an oft-cited passage from the Court's Grand Chamber judgment in Ilaşcu and Others v. Moldova and Russia. ${ }^{26}$ In this judgment, the Court asserted that

In determining the scope of a State's positive obligations, regard must be had to the fair balance that has to be struck between the general interest and the interests of the individual, the diversity of situations obtaining in Contracting States and the choices which must be made in terms of priorities and resources. Nor must these obligations be interpreted in such a way as to impose an impossible or disproportionate burden. ${ }^{27}$

From this passage, there are three key conclusions we can infer that can inform the discussion on the state's positive obligation to provide a socioeconomic protection under the ECHR. Firstly, the scope of the positive obligation is subjective to each state, owing to the diversity of situations to which the contracting parties are exposed. Secondly, in defining the scope of the obligation, due regard must be given to striking a fair balance between the needs of the individual and the general interest. In the socioeconomic arena, the state will be afforded a particularly wide margin of appreciation in this regard. Finally, the scope of the positive obligation must be such so as to be within the capabilities of the state. Put more simply, positive obligations cannot require the state to deliver the impossible. Specifically, in the context of socioeconomic rights, the Court has made reference to and endorsed the "proviso of the possible' approach, according to which 'a State cannot be forced to comply with its obligations in the framework of social rights if it does not possess the economic means to do so'. ${ }^{28}$

Thus, when the state's compliance with its positive obligations is examined, the prejudice to the victim is 'a necessary, but still an insufficient condition' ${ }^{29}$ to find that the state was in violation of these obligations. The significance of this analysis in relation to the state's socioeconomic obligations is that apart from the circumstances of deprivation the individual experiences that may engage her Convention rights, the Court must proceed to establish state fault in order to find a violation, namely that the state failed to take those steps that were necessary to protect the rightsholder. More specifically, the Court must identify 'a failure of the state that contributed to the prejudice the victim suffered', ${ }^{30}$ and/or that there 'were certain supplementary measures which the State could have taken but failed to take, although this would not have imposed a disproportionate burden'. ${ }^{31}$

\footnotetext{
${ }^{25}$ See Vladislava Stoyanova, 'Causation between State Omission and Harm within the Framework of Positive Obligations under the European Convention on Human Rights' (2018) 18 Human Rights Law Review pp 309-46.

${ }^{26}$ (App. No. 48787/99, 08 July 2004).

${ }^{27}$ Ibid at [332].

${ }^{28}$ Da Silva Carvalho Rico v Portugal (dec. App. No. 13341/14, 1 September 2015) at [44].

${ }^{29}$ See in detail Olivier De Schutter, International Human Rights Law (Cambridge University Press, 2014) pp 462

-518 at 479.

${ }^{30}$ See De Schutter and Ilaşcu and others v Russia and Moldova cited above at [332].

31 Ibid.
} 
In relation to this second limb of the required test to find a violation, where the Court must establish that there was state fault that caused harm to the right, the Court in socioeconomic cases affords states a very wide margin of appreciation. If the Court were to scrutinise state fault in socioeconomic cases intensely, in order to determine the capacity of the state to provide socioeconomic assistance, it would inevitably be drawn into sensitive areas of budget (re)allocation. Therefore, it is not surprising that the ECtHR acknowledges that it is out of its remit to place vast financial burdens on contracting parties. In the controversial and muchdiscussed case of $N v U K^{32}$ for instance, the Court held that the United Kingdom was not in violation of Article 3 ECHR when it deported an asylum seeker that suffered from AIDSrelated illnesses, due to the fact that in his state of origin he would be provided with a significantly lower standard of healthcare. The ECtHR stressed on this occasion that, while obligations of a social nature emanate from many of the rights protected under the Convention and require funds from the state, the ECHR is primarily directed towards the protection of civil and political rights. ${ }^{33}$ The difference in the level of healthcare provided between the two states was not a sufficient reason to create an obligation for the state to provide 'free and unlimited health care' ${ }^{34}$ to all who do not have a legal right to reside in the state. The Court reached its conclusion on the scope of the positive duty in this instance by taking into account the subjective dimension of the positive obligation to provide healthcare under the Convention. As the Court concluded controversially, a different interpretation of the Convention would create a particularly heavy burden on the contracting parties. ${ }^{35}$ Similarly, in Chapman $v U K,{ }^{36}$ the Court stressed that Article 8 ECHR does not guarantee a right to a shelter, due to the fact that such a decision would have obvious financial implications and is therefore a political one. For this reason, it was held that it did not fall under the Courts' jurisdiction to establish a socioeconomic duty on states to provide everyone with a home. ${ }^{37}$

The approach to socioeconomic rights in these judgments demonstrates that the Court is not identifying the content of a minimum core of socioeconomic obligations, nor is it establishing a pan-European social minimum of welfare protection that states are required to deliver. The Court in these instances refuses to extend socioeconomic protection under the ECHR on the basis that this may have unintended financial implications that would be too onerous on the contracting parties.

In practice, however, there are instances where the Court has found the state in violation of the Convention for failure to deliver on its socioeconomic duties without carrying out an exercise of determining whether these duties were within the state's means. These exceptional cases place duties on member states that seem to be objective in nature. The following section examines such instances in the Court's case-law and attempts to assess whether they hold any promise in generating a Convention-based social minimum of welfare protection.

\section{IV. 'Vulnerability' as a means to generate 'objective' obligations.}

\footnotetext{
${ }^{32}$ N. v United Kingdom (No. 26565/05, 27 May 2008).

${ }^{33}$ Ibid para 44.

${ }^{34}$ Ibid.

35 In subsequent cases, the Court has been more willing to provide protection to individuals in similar circumstances, by lowering the threshold of exceptional circumstances that would warrant state intervention. See Paposhviliv Belgium (App. No. 41738/10, 13 December 2016).

${ }^{36}$ (App. No. 27238/95, 19 January 2001) para 98.

${ }^{37}$ Ibid.
} 
The approach dictated by the nature of positive obligations discussed in the previous section may seem to paint a particularly disheartening picture for the capacity of the Court to create an absolute baseline of socioeconomic provisions from which all Contracting Parties to the ECHR cannot depart. In practice, however, the Court has demonstrated some attempts to create such objective duties on states. In order to do so, the Court had to identify a normative justification that would allow it to abandon its usual approach to socioeconomic obligations and proceed to a finding that an individual's circumstances were so dire so as to create the minimum core-type duty on the state. The key justification the Court has adopted is to focus on the applicant's membership to a vulnerable group. This section argues that while an absolute minimum of social protection is not guaranteed to all by the Convention, references to the applicant's vulnerability allow it to guarantee a social minimum to some. The justifications the Court relies on to identify these recipients of the social minimum will be discussed in this section.

The concept of 'vulnerable groups' has begun to feature prominently in the ECtHR's case-law. The Court's allusion to the applicant's vulnerability is not merely a 'rhetorical flourish ${ }^{38}$ but has legal effects. ${ }^{39}$ It is outside of the scope of the chapter to discuss the use of vulnerability in all its forms in the Court's case law. Instead, the focal point will be the use of vulnerability as a means for the Court to justify 'objective' socioeconomic duties of the state towards the vulnerable group.

The Court in this context has linked vulnerability to applicants who are "wholly dependent' ${ }^{40}$ on State support, and who have found themselves 'faced with official indifference when in a situation of serious deprivation or want incompatible with human dignity'. ${ }^{41}$ Under this understanding of vulnerability, the Court has assigned vulnerable status to prisoners, ${ }^{42}$ children in a state institution for minors with mental disabilities ${ }^{43}$ and to asylum-seekers among others. ${ }^{44}$ The key connecting factor seems to be they are all wholly dependent on state support for their subsistence. The state's duties intensify where children asylum-seekers enter a state on their own or in cases where the asylum-seeker is travelling with children. ${ }^{45}$ The obligation to protect also increases where the state's passivity to the needs of the asylum-seeker is the cause of, or compounds, their destitution. This would be the case for instance, where the state unduly delays responding to an asylum request, thus prolonging the plight of the applicants. ${ }^{46}$

For these categories of individuals, the state is expected to provide the necessary material assistance to ensure their survival. The Court in these instances does not carry out a thorough assessment of the capabilities of the state to secure these provisions. Especially in the context of persons in detainment, the Court expressly refuses to engage in a discussion on the capacity of the state to offer the rights-holder socioeconomic support. Gerards notes the farreaching socioeconomic obligations states owe towards prisoners under the Convention, including the provision of 'glasses, forearm prostheses or dentures, with a special diet or with

\footnotetext{
${ }^{38}$ On this see Lourdes Peroni and Alexandra Timmer, 'Vulnerable Groups: The Promise of an Emerging Concept in European Human Rights Convention Law' (2013) 11 International Journal Constitutional Law pp 1074.

${ }^{39}$ Ibid.

${ }^{40}$ MSS v Belgium and Greece (App. No. 30696/09, 21 January 2011) para 253.

${ }^{41}$ Ibid.

${ }^{42}$ See for instance G. v. France (App. No. 27244/09 Feb. 23, 2012) paras 72 and 77.

${ }^{43}$ Nencheva v Bulgaria (App. No. 48609/06, 18 June 2013).

${ }^{44}$ MSS v Belgium and Greece (App. No. 30696/09, 21 January 2011) and VM and others v Belgium (App. No. 60125/11, 7 July 2015).

${ }^{45}$ See VM and others $v$ Belgium (App. No. 60125/11, 7 July 2015).

${ }^{46}$ MSS v Belgium and Greece (App. No. 30696/09, 21 January 2011) para 263.
} 
medication'. ${ }^{47}$ In cases relating to such provisions state objections as to their cost do not sway the Court, especially where the Court relies on the vulnerability of prisoners to find Article 3 ECHR violations. In Poltoratskiy v. Ukraine ${ }^{48}$ for instance, a case where the applicant complained about the very poor prison conditions he was exposed to while on death row, the Court took note of that fact that 'Ukraine encountered serious socio-economic problems' ${ }^{49}$ and that authorities were 'struggling under difficult economic conditions'. ${ }^{50}$ This did not persuade the Court to alter its approach. The Court held that this 'lack of resources cannot in principle justify prison conditions which are so poor as to reach the threshold of treatment contrary to Article 3 of the Convention'. ${ }^{51}$ This approach leads Gerards to conclude that where the Court is examining the rights of individuals in detainment, the state's positive obligations 'are much stronger and the Court is much less deferential towards the States where budgetary considerations are concerned' ${ }^{52}$ According to Judge Sicilianos in his extrajudicial writings, in these circumstances where the state has sole responsibility for the well-being of the individual, the lines between positive and negative protection become blurred and 'the Court imposes on states a kind of obligation of result ${ }^{53}$ rather than one of means.

This underscores a particularly important function of vulnerability. As Bossuyt explains, vulnerability lowers the threshold for inhuman or degrading treatment, thus creating a link between the deprivation the individual faces and Article 3 ECHR. ${ }^{54}$ Due to the absolute nature of the right, any subsequent discussion on the state's capacity to respond to these obligations is rendered nugatory.

A similar approach is followed where asylum seekers are concerned. In the landmark judgment of M.S.S. v Belgium and Greece, ${ }^{55}$ the ECtHR found Greece in violation of Article 3 ECHR for the living conditions to which the applicant was exposed to while waiting for his asylum request to be processed. The fact that he was left without shelter and material provisions was sufficient for the Court to find that his circumstances had reached the minimum level of severity required for an Article 3 ECHR violation. The Court reached its conclusion by noting the obligations Greece had under EU law ${ }^{56}$ to provide a minimum of socioeconomic standards to asylum seekers. This analysis was complemented by reference to the vulnerability of asylum seekers. In subsequent judgments with similar facts, vulnerability was used as the sole basis to bring the applicant's situation into the realm of Article 3 and to justify the Court's finding of a Convention violation. ${ }^{57}$

\footnotetext{
47 Janneke Gerards, 'The ECtHR's Response to Fundamental Rights Issues Related to Financial and Economic Difficulties - the Problem of Compartmentalisation' (2015) 33 Netherlands Quarterly of Human Rights pp 284.

48 (App. No. 38812/97, 29 April 2003).

49 Ibid para 148 .

${ }^{50}$ Ibid.

${ }^{51}$ Ibid.

52 Janneke Gerards, 'The ECtHR's Response to Fundamental Rights Issues Related to Financial and Economic Difficulties - the Problem of Compartmentalisation' (2015) 33 Netherlands Quarterly of Human Rights pp 286.

${ }^{53}$ Alexandros-Linos Sicilianos, 'The European Court of Human Rights at a time of crisis in Europe' (2016) European Human Rights Law Review pp 124.

${ }^{54}$ Marc Bossuyt, 'Is the European Court of Human Rights on a slippery slope?' in Flogaitis, Zwart and Fraser (eds.), The European Court of Human Rights and its Discontents (Edward Elgar, 2013) pp 28-29.

55 (App. No. 30696/09, 21 January 2011).

${ }^{56}$ Council Directive 2003/9/EC of 27 January 2003 laying down minimum standards for the reception of asylumseekers in the member States.

${ }^{57}$ See for instance VM and others $v$ Belgium (App. No. 60125/11, 7 July 2015).
} 
The needs of the vulnerable demand an immediate response from the state and thus vulnerable status can serve as a guide to states on how to dispense their positive obligations, namely to which individuals to give priority for socioeconomic provisions. By bringing destitution into the scope of Article 3, the state cannot argue that providing socioeconomic assistance would be outside its subjective capabilities. Therefore, this approach fulfils the immediacy, completeness and universality requirements discussed in Part 1 of this chapter that Tasioulas associates with the social minimum. It does not, however, meet the requirements of Waldron's definition, as it is not a social minimum of provisions that is available to all. It is instead only limited to those groups the Court has deemed to be vulnerable.

This distinction between vulnerable and non-vulnerable individuals in need of social assistance could be faulted for leading to unfair results. In M.S.S. for instance, the Court was quick to point out that 'Article 3 cannot be interpreted as obliging the High Contracting Parties to provide everyone within their jurisdiction with a home' ${ }^{58}$ This clarified that the finding of the violation in this case was exceptional and not available to all who were destitute, but instead only to members of a vulnerable group. ${ }^{59}$ Thus, the Courts reliance on 'vulnerable groups' has a dual function. On the one hand, it increases the state's obligations to provide material assistance to vulnerable groups by allowing the Court to invoke Article 3 ECHR and consequently to forego a subjective test of the state's resource capabilities. On the other hand, the 'vulnerable groups' construct establishes the limits of this obligation. The duty is only owed to the members of vulnerable groups, thus excluding other individuals that may have equally pressing socioeconomic needs but are not able to claim membership to a group the Court has identified as vulnerable.

To illustrate this point by way of an example, if we are to imagine two destitute individuals, one (A) who is a citizen of the state sleeping rough on the streets, and the other (B) an asylum seeker who is exposed to the same levels of deprivation during the time their request for asylum is being processed, the Court's approach would mean that individuals A and B would have very different prospects of success before the ECtHR. For A to successfully challenge her destitution on Convention grounds, she must demonstrate that for instance, she was discriminated against and unlawfully excluded from a state-run housing scheme, or that there were procedural flaws in how her case was dealt with, assuming the state in question offers shelters to the homeless in the first place. The ECtHR would most likely afford the state a wide margin of appreciation. The hurdle for B to satisfy her socio-economic demands under the Convention is much lower. The Court's justification for this would be that B has no option but to rely exclusively on the state for her subsistence. Thus, the scope of the positive obligation, the state's duty to protect, is much more pressing in B's case. The state's margin will be narrow, and the ECtHR will most likely find B's treatment to violate the Convention in line with the Court's case law on asylum-seekers. Importantly, this will be an objective duty the state must fulfil, and not one that is based on the subjective capabilities of the state. Consequently, the same degree of deprivation leads to differing human rights obligations under the ECHR as interpreted in the case law of the ECtHR.

\footnotetext{
${ }^{58}$ MSS para 249.

${ }^{59}$ See concurring opinion of Judge Rozakis in MSS.
} 
The assumption that A should be more self-reliant and is therefore less deserving of protection may be criticised for failing to identify various layers of vulnerability ${ }^{60}$ or the complexities of life that could lead someone to destitution. This aspect of vulnerability as it is understood by the ECtHR also explains why this tool to enhance positive obligations has been criticised. As commentators have pointed out, the term is exclusionary as it suggests that individuals who are not readily identifiable as members of a vulnerable group are viewed as 'self-sufficient, independent and autonomous', ${ }^{61}$ and concomitantly less worthy of protection.

One could be tempted to argue that the Court should simply build on its vulnerability analysis to include more classes of individuals in its ambit. If vulnerability unlocks state obligations to provide a social minimum of welfare assistance, expanding the pool of individuals who would qualify as vulnerable would allow the Court to require more from states. With this in mind, the following section will address whether expanding the concept of vulnerability to encompass a broader range of individuals in need of social assistance would in fact be useful.

V. From 'vulnerable groups' to individual vulnerability: An inflation of vulnerability analysis?

The previous section has argued that the vulnerable status of an individual can be the means to make subjective obligations objective and to require the state to fulfil a minimum of the individual's socio-economic needs. This raises a related question. If vulnerability serves such a function, and the aforementioned distinctions the Court makes between vulnerable and nonvulnerable individuals can be criticised for leading to unfair results, should the Court broaden the category of those who can lay claim to vulnerability? Prima facie, if the Court were to assign vulnerable status to applicants based on their specific needs rather than their membership to a group or the level of responsibility the state purportedly has over them, it could simultaneously adopt a bolder stance in its socioeconomic jurisprudence. This could allow the Court to justify narrowing the margin of appreciation or to demand a greater degree of socioeconomic provisions from the respondent states.

The Court has clearly not followed an understanding of vulnerability that is linked to the specific needs of the applicant. ${ }^{62}$ As Brandl and Czech confirm, in the ECtHR's case law 'vulnerability is not derived from an applicant's individual personal circumstances, but from his or her affiliation to a group with special needs' ${ }^{63}$ The Court may identify various degrees of vulnerability within the vulnerable group, ${ }^{64}$ or recognise 'double vulnerability' ${ }^{65}$ where the applicant possesses characteristics that classify her under more than one group that has been

\footnotetext{
${ }^{60}$ See especially Martha Fineman, 'The Vulnerable Subject and the Responsive State' (2010) 60 Emory Law Journal pp 251 - 75;

${ }^{61}$ Lourdes Peroni and Alexandra Timmer, 'Vulnerable Groups: The Promise of an Emerging Concept in European Human Rights Convention Law' (2013) 11 International Journal of Constitutional Law pp 1060.

${ }^{62}$ Alexandra Timmer, 'A Quiet Revolution: Vulnerability in the European Court of Human Rights' in Fineman and Greer (eds), Vulnerability: Reflections on a New Ethical Foundation for Law and Politics (Routledge, 2013) pp152.

${ }^{63}$ Ulrike Brandl and Philip Czech, 'General and Specific Vulnerability of Protection-Seekers in the EU: Is there an Adequate Response to their Needs?' in Ippolito and Iglesias Sánchez (eds), Protecting Vulnerable Groups: The European Human Rights Framework (Hart, 2015) 249.

${ }^{64}$ Alexandra Timmer, 'A Quiet Revolution: Vulnerability in the European Court of Human Rights' in Fineman and Greer (eds), Vulnerability: Reflections on a New Ethical Foundation for Law and Politics (Routledge, 2013) pp 161.

${ }^{65}$ Ibid.
} 
assigned vulnerable status. It does not, however, adopt a vulnerability-based analysis where the applicant is not a member of one of the vulnerable groups recognised as such in the Court's case law. If the Court were to abandon an understanding of vulnerability that is derived from the identity of the applicant, and instead chose to focus on the specific needs of the individual, it could, in theory, more confidently proceed to examine the circumstances of deprivation the individual is facing, and assess whether these would qualify as circumstances 'incompatible with human dignity', ${ }^{66}$ thus building on the approach the Court adopted in its asylum-seeker case law.

Such a hypothetical approach would find support in the broader literature on vulnerability. Fineman firmly rejects the notion of 'vulnerable groups', where vulnerability is linked to the identity of the individual. For Fineman, vulnerability is 'universal and constant' due to our embodiment as human beings, ${ }^{67}$ a shared characteristic rather than one that relates only to specific marginalised groups.

Fineman cautions against the stigmatising effect ${ }^{68}$ that the 'vulnerable groups' construct may have and instead argues in favour of building resilience, which is the 'solution to our vulnerability'. ${ }^{69}$ Under Fineman's vulnerability analysis,

the basis for distinguishing some individuals from better-positioned but equally vulnerable individuals in the first instance would revolve around questions of access to sufficient resources, with a deficit indicating they lacked the resilience that is necessary to address human vulnerability. Significantly, the initial emphasis here is on the distribution or allocation of resources and the structures within which they are produced. This suggests that the first question to be considered is whether institutional, not individual, functioning is inadequate. This inquiry shifts the focus to state and social responsibility because it recognizes that a deficit in resources often reflects an institutional or societal failing more than an individual one. ${ }^{70}$

Therefore, under Fineman's analysis, the destitute individual A in the example mentioned in the previous section should expect the same level of protection as destitute individual B. Her lack of 'resilience' would not be attributable to her own failings but be viewed as a state failure to protect her interests. Therefore, for Fineman, it would be incorrect to assume that she is more responsible for her plight than $\mathrm{B}$ due to the fact that A is not a member of a 'vulnerable group' or is not 'wholly reliant' on state support in the same way as a prisoner or an asylum-seeker. Thus, rather than focusing on the identity of the applicant, the Court could engage in a discussion on whether the applicant's circumstances offend her dignity in a manner that would render her vulnerable and trigger Convention protection.

ECtHR judges have taken some tentative steps in this direction in their extrajudicial writings, but such an approach has yet to enter the Court's analysis. Judge Tulkens, for instance,

\footnotetext{
${ }^{66}$ The Court employed this terminology in MSS at paras 220, 221 and 253.

${ }^{67}$ Martha Fineman, 'The Vulnerable Subject: Anchoring Equality in the Human Condition' (2008) 20 Yale Journal of Law and Feminism pp 1-23.

${ }^{68}$ According to Fineman, 'labelling some individuals and herding them into 'populations' defined as differently or particularly vulnerable (and therefore somehow inadequate) stigmatizes those individuals' see Martha Fineman, 'Vulnerability and Inevitable Inequality' (2017) 4 Oslo Law Review pp 133-149, available at https://www.idunn.no/oslo_law_review/2017/03/vulnerability_and_inevitable_inequality.

${ }^{69}$ Ibid.

${ }^{70}$ Ibid.
} 
argues that '[i]t would be unthinkable not to consider that extreme poverty humiliates the individual in his own eyes and in the eyes of others and is such as to arouse feelings of fear, anguish and inferiority' ${ }^{71}$ in a manner that would engage Article 3. Additionally Tulkens questions whether it would really be 'so ridiculous to think that if corporal punishment in schools is considered to be degrading, the same should apply to the situation of someone who 'lives' in a slum?' ${ }^{72}$ She does however accept that 'almost as a matter of necessity, [there must be] a certain degree of restraint in applying [this] in practice'. ${ }^{73}$

The approach Judge Tulkens recommends has some obvious benefits. It examines the impact of extreme poverty on the individual without reference to her membership to a vulnerable group. It is instead the feelings of 'fear, anguish and inferiority', caused by poverty, that could render the individual vulnerable and trigger obligations on the state to provide a certain baseline of protection.

While this analysis may seem attractive as a means for the Court to broaden the circumstances where an objective state obligation to protect would be triggered, there are important reasons that justify a restrictive understanding of who is vulnerable in the eyes of the ECtHR. A needs-based approach to vulnerability must not be interpreted by the Court as allowing it to generate onerous demands on the member states. As discussed in the previous section, an important function of vulnerability analysis is that it serves as a normative justification to allow the Court to narrow what would normally be a wide margin of appreciation. Vulnerability 'operates as a magnifying glass " ${ }^{74}$ for the state's duty of protection, allowing the Court to avoid the light touch review usually associated with socioeconomic rights. Therefore, the nature of vulnerability is exceptional in that it is a tool that exceptionally allows the Court to use the Convention as a means to satisfy basic socioeconomic needs. Thus, while the Court's approach to vulnerability can be criticised, if the proverbial net of vulnerability were cast too wide to include a much broader range of individuals, this tool would be in danger of losing its exceptional character that provides the Court with the justification to make the leap from subjective duties to objective socioeconomic demands. Therefore, any development in vulnerability analysis must be cognizant of the limits placed on the Court by its nature as a subsidiary human rights body and the fact that the Convention primarily protects civil and political rights. An inflation of the concept would call into question the Court's legitimacy to interpret the Convention in a manner that creates duties far exceeding those the contracting parties agreed to respect and protect.

A potential solution to this concern could be for the Court to reconcile both approaches to vulnerability in its reasoning. While relying primarily on the concept of vulnerable groups, the Court's analysis could more deftly engage in a discussion on the circumstances of the applicant and how these would trigger the state's duty to provide a minimum of protection. The fact that a person falls within a recognised vulnerable group could be viewed by the Court as a strong indicator of need, thus requiring the state to intervene. It would not, however, be the

\footnotetext{
${ }^{71}$ Judge Tulkens, 'Seminar to mark the opening of the judicial year of the European Court of Human Rights' (Strasbourg, 25 January 2013) available at http://echr.coe.int/Documents/Speech_20130125_Tulkens_ENG.pdf at para 19.

${ }^{72}$ Ibid at 20.

${ }^{73} \mathrm{Ibid}$.

${ }^{74}$ See Ana Beduschi, 'Vulnerability on trial: protection of migrant children's rights in the jurisprudence of international human rights courts' (2018) 36 Boston University International Law Journal pp 56.
} 
sole indicator. By further exploring the links between the applicant's situation of poverty and the state's duty to protect, the Court could incrementally ${ }^{75}$ develop a more coherent and consistent test to determine the circumstances under which the state would be required to provide a social minimum of welfare. This could open up state responsibilities towards individuals who would not be considered members of a vulnerable group. This approach secures the socioeconomic privileges vulnerable groups currently enjoy, but also allows the Court to slowly build its jurisprudence in the direction of specifying a certain minimum of protection that would be available to all who would need it.

The introduction of clearer and more coherent principles that link poverty to the state's duty to protect, would allow the Court to draw on these principles when the applicant's destitution reaches a level of severity that is incompatible with human dignity. This would not constitute a significant departure from the Court's existing legal reasoning. In obiter statements the Court has already identified that 'a complaint about a wholly insufficient amount of pension and the other social benefits may, in principle, raise an issue under Article 3, ${ }^{76} \mathrm{~A}$ similar approach was adopted in Budina $v$ Russia ${ }^{77}$ where the Court in obiter statements linked destitution to Article 2 ECHR. ${ }^{78}$ Building on this approach would ensure that such statements are not merely 'teasing promises" ${ }^{79}$ the Court makes obiter and is unlikely to fulfil, but can instead become the basis for a social minimum of welfare protection under the ECHR.

\section{Conclusion}

This chapter has attempted to examine the Court's socioeconomic case law through the prism of positive and minimum core obligations. It has argued that the nature of positive obligations as obligations that are subjective to each state and are obligations of means, suggesting that the Court may be limited in its capacity to establish a social minimum of welfare protection in absolute terms. The chapter then proceeded to examine an important tool the Court has relied on to require states, regardless of their resources, to intervene to protect individuals from destitution. The Court has established objective duties of protection in circumstances where the applicant is vulnerable and relies exclusively on the state for material support. The Court's case law on socio-economic provisions for asylum seekers is a particularly useful example of this approach. While the designation of a group as vulnerable and deserving of material assistance with priority against others may raise concerns, the exceptional nature of vulnerability allows the Court to expand the state's duties, thus overcoming the limitations inherent in positive obligations. While it would be useful for the Court to develop its understanding of vulnerability and to focus on the needs of the specific applicant rather than on her identity, the exceptional character of the vulnerability must be safeguarded. Therefore, an approach that reconciles the vulnerable groups approach with the applicant's individual

\footnotetext{
${ }^{75}$ On the Court's use of incrementalism see Janneke Gerards, 'Margin of Appreciation and Incrementalism in the Case Law of the European Court of Human Rights' (2018) 18 Human Rights Law Review pp 495-515.

${ }^{76}$ Larioshina v Russia (App.No. 56869/00, dec, 23 April 2002).

77 (App. No. 45603/05, dec, 18 June 2009).

78 On these cases see Dimitrios Kagiaros, 'In search of a 'social minimum': Austerity and destitution in the European Court of Human Rights' (2019) 25 European Public Law (forthcoming, on file with the author).

${ }^{79}$ Colm O'Cinneide, A Modest Proposal: Destitution, State Responsibility and the European Convention on Human Rights (August 30, 2008). Available on SSRN: https://ssrn.com/abstract=1370241 or http://dx.doi.org/10.2139/ssrn.1370241.
} 
needs would be a promising path for the Court to follow in the direction of establishing a social minimum of welfare provisions.

\section{Bibliography}

Ana Beduschi, 'Vulnerability on trial: protection of migrant children's rights in the jurisprudence of international human rights courts' (2018) 36 Boston University International Law Journal pp 55-85.

Marc Bossuyt, 'Is the European Court of Human Rights on a slippery slope?' in Flogaitis, Zwart and Fraser (eds.), The European Court of Human Rights and its Discontents (Edward Elgar, 2013) pp 27-36.

Olivier De Schutter, International Human Rights Law (Cambridge University Press, 2014).

Martha Fineman, 'The Vulnerable Subject: Anchoring Equality in the Human Condition' (2008) 20 Yale Journal of Law and Feminism pp 1-23.

Martha Fineman, 'The Vulnerable Subject and the Responsive State' (2010) 60 Emory Law Journal pp $251-275$.

Martha Fineman, 'Vulnerability and Inevitable Inequality' (2017) 4 Oslo Law Review pp 133-149.

Janneke Gerards, 'The ECtHR's Response to Fundamental Rights Issues Related to Financial and Economic Difficulties - the Problem of Compartmentalisation' (2015) 33 Netherlands Quarterly of Human Rights pp 274-92.

Janneke Gerards, 'Margin of Appreciation and Incrementalism in the Case Law of the European Court of Human Rights' (2018) 18 Human Rights Law Review pp. 495-515.

Ida Elisabeth Koch, Human Rights as Indivisible Rights: The Protection of Socio-Economic Demands under the European Convention on Human Rights (Martinus Nijhoff Publishers, 2009).

Laurens Lavrysen, Human Rights in a Positive State (Intersentia, 2016).

Ingrid Leijten, Core Socio-Economic Rights and the European Court of Human Rights (Cambridge University Press, 2017)

Alastair Mowbray, The Development of Positive Obligations Under the European Convention on Human Rights by the European Court of Human Rights (Hart, 2004).

M. Neal, 'Not Gods but Animals: Human Dignity and Vulnerable Subjecthood' (2012) 33 Liverpool Law Review pp 177-200.

Colm O'Cinneide, A Modest Proposal: Destitution, State Responsibility and the European Convention on Human Rights (August 30, 2008). Available at SSRN: https://ssrn.com/abstract=1370241 or http://dx.doi.org/10.2139/ssrn.1370241 
Ellie Palmer, 'Beyond Arbitrary Interference: The Right to a Home? Developing Socioeconomic Duties in the European Court of Human Rights' (2010) 61 Northern Ireland Legal Quarterly pp 225-43.

Lourdes Peroni and Alexandra Timmer, 'Vulnerable Groups: The Promise of an Emerging Concept in European Human Rights Convention Law' (2013) 11 International Journal Constitutional Law pp 1056-85.

Alexandra Timmer, 'A Quiet Revolution: Vulnerability in the European Court of Human Rights' in Martha Fineman and Anna Greer (eds), Vulnerability: Reflections on a New Ethical Foundation for Law and Politics (Routledge, 2013) pp 147-70.

Alexandros-Linos Sicilianos, 'The European Court of Human Rights at a time of crisis in Europe’ (2016) European Human Rights Law Review pp 121-35.

Vladislava Stoyanova, 'Causation between State Omission and Harm within the Framework of Positive Obligations under the European Convention on Human Rights' (2018) 18 Human Rights Law Review pp 309-46.

John Tasioulas, 'Minimum Core Obligations: Human Rights in the Here and Now' (2017) http://documents.worldbank.org/curated/en/908171515588413853/pdf/122563-WP-

Tasioulas2-PUBLIC.pdf

Jeremy Waldron, 'John Rawls and the Social Minimum' (1986) 1 Journal of Applied Philosophy pp 21-33. 